\title{
The Role of Accounting Reform in Deterring Corruption Practices in the Public Sector: A Case Study in Kurdistan Region
}

\section{Ghaffoori A*}

Department of Accounting, Essex Business School, UK

\begin{abstract}
There is an increasing focus on the subject of corruption around the world. The aim of this research is to investigate the impact of accounting reform on Kurdistan region with respect to corruption. The methodology used in this study is the qualitative interpretive method and the main tool for collecting data was the semi-structured interviews, through a case study on the Kurdistan region (Iraq). According to the literature and findings of this research, there is a relationship between the accounting system and corruption. Further, an efficient accounting system is regarded as one of the effective anti-corruption strategies. The Kurdistan region can increase the level of accountability and transparency in the public sector by reforming its current accounting processes, which will thus lead to the reduction in cases of corruption. Some essential changes have been suggested by the respondents to increase government accountability and transparency such as shifting from cash-basis to accrual-basis accounting, adopting international accounting standards, changing budget system from input-line to performance programme budget system, strengthening audit especially external auditors, updating the accounting curriculum and computerising the accounting system. These will improve the accounting system and thus aid in fighting corruption.
\end{abstract}

Keywords: Accounting; Corruption; Kurdistan region; Public sector

\section{Introduction}

Corruption is a very complicated and debatable phenomenon. Many definitions have been used to determine its meaning, while there is no one universally accepted definition [1]. However, corruption, in simple terms, means a person or an organisation who takes advantage of money or position, whether in the public sector or the private sector in order to achieve purely individual gains [2].

Corruption is a barrier that postpones the economic development of a country [3]. The World Bank indicated in its annual report, in 1997, that corruption is a serious threat that hinders the social and economic development, increases social inequality, and perpetuates poverty [4]. In addition, it impedes the enhancement of the quality of general services which are delivered by governments for the poor citizens and rural areas, especially in the developing countries. Its impacts are not only on the government institutions or private sector, but also on the society as a whole [5].

Spector states that in the developing countries, corruption is regarded as the most dangerous problem and has more negative impacts there than in the developed countries [6]. Sandholtz and Koetzle argue that corruption is a big challenge for developing countries [7]. Further, Koetzle argues that corruption has affected many aspects of life and created many economic, financial, educational, administrative, and social problems. Thus, fighting corruption in developing countries is regarded as the essential step towards economic development.

Corruption occurs in public and private sectors and has negative impacts on both these sectors. In the private sector, it reduces competition, weakens efficiency, and effectiveness, and increases the cost of businesses. In the public sector, it increases the general expenses, decreases the amount of taxation and thus, increases financial deficits and creates macroeconomic uncertainty [8]. Therefore, fighting corruption is not limited to only the government, but all parties that take part in this fight.

In this regard, one of the anti-corruption strategies suggested by the previous literature is the reformation of accounting systems. Malagueño et al. explain that corruption has a relationship with the accounting system. Any country can strive to reduce the level of corruption by strengthening its accounting and auditing systems [9].

According to Ouda, the accounting system in many developing countries is still traditional and unable to fight corruption. Therefore, this paper aims to study the impact of accounting reforms on corruption practices in the Kurdistan region of Iraq (which is the case study of this research) [10].

\section{The research aim}

As the accounting system in majority of developing countries is traditional and weak, including the Kurdistan region (case study), the study aims to investigate the role of accounting reforms in deterring corruption practices in the public sector in the Kurdistan region (more information about Kurdistan region is provided in chapter three).

\section{The research question}

With regard to the corruption practices, Kurdistan region, like many other developing countries, is suffering from a high level of corruption in its government structure. As for its financial and accounting system, there is a lack of proper accounting system. Thus, the main research question is "What is the role of accounting reform in deterring corruption practices in government sector in Kurdistan region?"

\section{The important of the research}

Through reviewing the literature on this subject, it can be concluded

*Corresponding author: Arsalan Ghaffoori, Department of Accounting, Essex Business School, Wivenhoe Park, Colchester CO4 3SQ, UK, Tel: +441206873333; E-mail: aqmgha@essex.ac.uk

Received November 07, 2016; Accepted November 29, 2016; Published November 30, 2016

Citation: Ghaffoori A (2016) The Role of Accounting Reform in Deterring Corruption Practices in the Public Sector: A Case Study in Kurdistan Region. J Bus Fin Aff 5 : 229. doi: 10.4172/2167-0234.1000229

Copyright: (c) 2016 Ghaffoori A. This is an open-access article distributed under the terms of the Creative Commons Attribution License, which permits unrestricted use, distribution, and reproduction in any medium, provided the original author and source are credited. 
that there are a considerable number of studies about corruption and its negative impacts in developing countries. However, there is no particular case study on the Kurdistan region about corruption and the relationship with its accounting system. This research will be important, because it is regarded as the first study of the Kurdistan region about accounting system and corruption.

\section{The research methodology}

The method chosen for this research is the qualitative interpretive approach. It uses a case study (Kurdistan region). The tool for collecting data is semi-structured interview (research methodology chapter three).

\section{Organization of the research}

In order to achieve the research aim, this research has been divided into five chapters.

Chapter one deals with the introduction. It illustrates the background of the research, research aim, the research question, the methodology, and the research importance.

Chapter two is the literature review, which explains corruption and its main definitions, other topics such as corruption in developed and developing countries, corruption and its relationship with accounting system, accounting system in developing countries and finally formulated the research question.

Chapter three talks about the methodology. It illustrates the chosen qualitative method, interpretive paradigm, case study, and background information about the Kurdistan region, steps in case study, and the semi-structured interview process.

Fourth chapter is about data analysis and discussion. It includes the themes of interview process and discusses the findings.

Chapter five refers to the conclusion, limitations and ethical considerations.

\section{Literature Review}

\section{Introduction}

This chapter constructs the research question through reviewing relevant previous literature. It explains why accounting system is regarded one of the anti-corruption strategies. Relevant literatures have been reviewed in order to make establish a connection between different studies. The review focuses on the relationship between corruption and accounting system and the extent to which accounting reform is a necessary in preparing countries to fight corruption.

\section{Background}

Corruption is considered to be a big human concern. It is found in all civilisations and societies throughout history, regardless of the civilisation's size and level of prosperity [11]. Throughout history, each civilisation had contributed in developing corruption concepts. Further, factors such as cultural, ethical, and political, and management systems may have contributed to the occurrence and the increase of corruption [12].

Corruption is a global problem and has negative impacts on all countries around the world. There is no doubt that corruption is the most dangerous problem in the 21st century, particularly in the poor and developing countries [13]. Since the last decade of the 20th century, corruption has been considered a main player in the global agenda [14]. It has drawn the attention of many academic researchers around the world [15]

\section{Definition of corruption}

There is a necessity of having a clear understanding of corruption phenomenon. This section will discuss many definitions of corruption that have been developed by scholars in order to provide a clear understanding.

Lambsdorff argues that corruption is a very complex phenomenon that is not easy to define, due to its several types and forms [16]. Along the same lines, Rabl claims that there is no comprehensive definition of corruption [17]. However, there are some definitions that express the main features of corruption.

The common definition of corruption is the use of public office for private gain [13]. A similar definition was given by the Transparency Organisation in 2006, the abuse of entrusted power for private gain' [18]. According to these definitions, corruption is linked only to the public sector, even though, the fact is that corruption occurs in both public and private sectors. For example, a person may try to use his/her position in a private organisation for personal gain [7].

It is clear from the above definitions that corruption in any form is an illegal act; some of these forms are fraud, bribery, nepotism, extortion, speed money, graft, embezzlement, pilferage, falsification and manipulation of records, theft, kickbacks, and influence peddling. Corruption primarily happens in the public sector. It also happens in other areas of governance, such as the enterprise sector, political parties, and NGOs [19].

\section{Categories of corruption}

USAID classifies corruption into two categories: systemic and spontaneous [20]. Firstly, the systemic corruption is usually found in communities where corrupt practices are widespread and perennially. In these communities, corruption is common and a way of life; people use it in order to gain private interests. It seems that systemic corruption is widespread in developing countries, where the political governance system is weak. Secondly, spontaneous corruption often occurs in developed communities that control ethics in the public sector.

\section{Forms of corruption}

According to the argument of Deflem [21], there are two types of corruption: monetary and bureaucratic. With regard to the framework of this research, monetary corruption of the public sector will be studied. The monetary corruption includes many forms such as bribery, fraud, embezzlement, favouritism, and money laundering. The terms have been explained as follows:

Bribery is regarded as a common form of corruption [22]. It is an amount of money that is received by an official person, who has a post either in the public sector or in the private sector, when he/she fulfils a particular task for a particular person [23].

Fraud is described as something that is similar to financial injuries [24]. Fraud is usually regarded as an economic scandal that involves such terms as swindle and deceit. Fraud occurs when an official person, who is responsible to perform a particular task, performs these tasks illegally by manipulating the documents for his private gain [25]

Embezzlement may be regarded as a kind of theft [25]. It happens when a dishonest agent steals from his employer by abusing or misappropriating the assets of an organisation for private gain [25]. 
Further, Okafor adds another view point entrusted power for private gain" $[18,26]$. According to these definitions, corruption is linked only to the public sector, even though, the fact is that corruption occurs in both public and private sectors. For example, a person may try to use his/her position in a private organisation for personal gain [7].

\section{Corruption in developed countries}

Campos et al, explains that corruption is a global problem and does not directly relate to a particular country or region [13]. Corruption is without borders, that exists everywhere and creates various problems for governments, firms, businesses, people, and society in many countries, whether they are developed or developing. However, certainly, the level of corruption in developing countries is higher than in developed countries. In the light of this, Sandholtz and Koetzle state that corruption has a priority for discussion in agendas of international platforms such as the International Monetary Fund, World Trade Organization, and World Bank [7]. As a result, many suggestions are being proposed internationally for developing anti-corruption strategies and helping poor nations to fight corruption.

In relation to developed and industrialised countries, there are studies which indicate that the level of corruption recently has increased in developed countries. For instance, MacDonald and Majeed conducted a study about corruption in European countries [27]. According to the result, corruption has increased in many European countries. They state those three decades ago, the average level of corruption in European countries was 0.74 units. This level has increased to 2.12 units in 2007. They state that "this is an alarming figure and surely needs to be rapidly addressed. Further, they argued that corruption cases can be found even in countries known as corruptionfree such as Finland, Sweden, and Denmark.

Another study that supports this argument indicates that about European countries [28]. The author states that, for many years corruption was seen as a problem only for poor countries, while economic crises in European countries strongly indicates that controlling corruption is difficult. For instance, in countries like Greece, Italy, Portugal, and Spain, economic situation has regressed rather than progressed. According to Special European Survey, 79\% of the participants fully or partially agreed that corruption exists in their countries.

These studies reveal that there is no country without any instances of corruption. It rejects the idea of economists and development practitioners that corruption is a problem only for developing countries. However, it is important to acknowledge that in developing countries, the level of corruption is relatively high, where a systemic corruption exists, hence, calling for more efforts to fight corruption.

\section{Corruption in developing countries}

The economic and political situations in developing countries indicate that there are very small numbers of developing countries that have low levels of corruption cases [3]. Thus, corruption poses a significant challenge for the developing countries and is regarded as a serious threat. It has created many economic, financial, cultural, educational, management and social problems [7]. Shabbir and Anwar argue that in developing countries [29], if the level of corruption increases by $1 \%$, it will lead to a decline in the gross domestic products by about $3 \%$. In addition, Lambsdorff conducted a study and reached a similar result [16]. The result of the study shows that corruption affects investment, especially foreign investment, reduces the general domestic product (GDP), generates poor institutional quality, increases public expenditure, and reduces the income and tax collection, international capital flow, and international goods and aids.

Another important sector had been influenced by corruption is the education sector. A recent study conducted by Campos et al. illustrates that corruption affects the education process. The study collected data from 50 countries [13]. According to the study's findings, corruptors have taken advantage of the education budget because countries usually allocate high percentages of budget, about $30 \%$ yearly, for this sector. The education budget is not spending according to the requirement of the sector. Further, in regard to the teaching process in education centres, the scientific and logical rooting at the graduation of students has been disregarded, thus, yielding poor education outcomes. As stated by Chapman, corruption permeates the day-to-day transactions at the classroom, school, and district levels. The real damage to a society occurs when entire generations of youth are mis-educated by example to believe that personal success comes not through merit and hard work, but through favouritism, bribery, and fraud. Such lessons have the potential to undermine civil society well into the future [30].

According to the studies which have studied the impacts of corruption in developing countries, it is clear that corruption has brought many problems for these countries. Nonetheless, few arguments have been made regarding the positive impacts of corruption. For example, Bardhan argues that corruption affects positively the economy of a country and increases the effectiveness of the private sector and encourages trade [31].

Another argument about the positive impact of corruption has been made by Rock and Bonnet [32]. They claim that corruption in new industrialised countries such as East Asian countries has positive impacts on investments and has increased growth. For instance, Leff argues that in such an environment, bribery could help investors by providing an opportunity to attain government licenses [33]. It may allow businesses to avoid unnecessary and heavy delays. Further, corruption could increase the investments by lowering the risk of a volatile government. The government may intervene harmfully in an investor's project.

However, it seems that the positive impacts may be the case only for a short time, and at some stages, the growth trends will decrease due to corruption causing distractions in the socio economic system of a country. In other words, corruption will naively impact the citizens, especially the poor people and those who have no relationship with the political authority [1].

Thus, through the above discussion, it is clear that in the developing countries systemic corruption exists and therefore its impacts are higher than in the developed countries. Therefore, in developing countries fighting corruption becomes more difficult than in developed countries. They need to take into account many the political aspects, management and control system, and the ethical, social, and cultural aspects.

According to many studies, which have been conducted on the subject of corruption, this chapter aims to display the link between corruption and the country's accounting system. If, in a country, an efficient accounting system exists, the level of corruption could possibly be low.

\section{Corruption and accounting system}

Everett et al. conducted a study, examining the role of accounting in the global fight against corruption [34]. They state that accounting 
and auditing systems have an important role in any organisation. According to them, accounting is an information system that provides information about economic entities through financial statements and reports. These statements and reports are important for decision makers. Audit is a monitoring system, which provides neutral and professional opinions about the financial statements. Further, they state that, Accounting serves a dual role: Financial statements provide information about economic transactions, and the auditing profession serves as a monitoring mechanism to check on the accuracy of this information Accounting as an information system, and auditing as a monitoring or check on the accuracy of the accounting information system, provide an enormous potential for establishing accountability and detection of corrupt activities [34].

A similar argument is made by Malagueño et al. [9]. They conducted a study to discover the existence of a relationship between accounting and auditing and the level of corruption. The authors have collected data by a cross-country survey. They found out practical evidence that the level of corruption in a country enormously depends on its accounting and audit systems. According to the findings, financial reports with high transparency and disclosure show a lower level of corruption. Malagueño et al. argue that any country will be able to reduce the level of corruption by strengthening its accounting and audit systems [9].

They point out that stakeholders can assess the organisation's performance through accounting and audit reports; these reports allow them to make decisions in a relevant time. However, since a poor accounting and control system does not provide accurate financial reports they become less reliable for stakeholders while making decisions. In addition, poor accounting and auditing systems generate a situation that makes it easier for employees to work against accounting and auditing rules for fulfilling private gains. In this context, state this is an important discovery because if, as our research suggests, better accounting and audit systems are associated with less perceived corruption, then governments may be able to decrease corruption by improving accounting and audit standards thus improving their business climate, encouraging investment by both nationals and foreigners and increasing overall their productivity and GDP.

Another study has been conducted by Wu about corruption in corporate sector of Asian countries [35]. The author indicates that the accounting system is one important element of a management system and has a great role to detect cases of corruption, especially the bribery and fraud cases. In addition, he found out that many Asian countries still have a poor accounting and control system. He claims that the main factors that have led to the financial crisis in the Asian countries in 1997 were the low quality of accounting and auditing standards. He states that, as a result, some Asian countries have changed their accounting systems and adopted International Accounting Standards (IAS) and some other modern accounting techniques to avoid financial crisis in the future. Currently, one can see a considerable progress in relation to accounting and auditing aspects.

These studies reveal that accounting and audit systems are an important element in the organisational structure for all organisations whether in the public or private sector. They also show that there is a relationship between the accounting system and corruption practices. When good accounting and auditing systems exist, there is low level of corruption and vice versa. However, the question here, in relation to developing countries, is about the ability of accounting system to answer the requirements of new age and its potential to fight corruption.

\section{Accounting system}

Before illustrating the accounting system in developing countries, there is a need to understand to the role of accounting system in general. Accounting is an information system which is regarded as an essential part in an organisational structure. It provides financial information to the related parties, whether internal or external. Audit is a part of the accounting system which verifies the information provided by the accounting system. Accounting and auditing system together work to produce accurate, relevant, comparable, and transparent information. Thus, in this case, accounting system is considered to actively contribute in a country's economic development [36]. The accounting contribution was confirmed by the World Bank. The World Bank in 1997 emphasised the role of an accounting system in strengthening a country's economic development by stating that, - there is no doubt that weak accounting and auditing capabilities, as well as the high incidence of financial mismanagement in the public and private sectors are major constraints to sustainable economic development.

Traditionally, the role of an accounting system is merely to provide financial information about an organisations' performance for interested parties, in order to facilitate decision making. However, the role of an accounting system has evolved significantly, especially in the developed countries. It now ensures concepts of transparency and accountability, not only in public organisations, but also in the private organisations and in the wider scope of national economic development as well. In other words, it provides to citizens the financial and non-financial information about an organisations' performance, whether they are public or private. In addition, it has an active role in the socio-economic development by providing information about the general national income, general resources, social values, fairness, and environmental considerations [29].

\section{Accounting change}

Barth et al. argue that some factors have affect the accounting system [37]; these include increasing international trades, international flow capital and foreign investment, financial crisis and accounting scandals, information technology and globalization process. These factors have encouraged accounting federations and associations in some developed and industrial countries to invent and change the existing accounting system to improve it to deal with the new and competitive era. As a result, the international accounting and auditing standards have been issued.

The majority of countries, especially developed countries, made the essential changes in their accounting system and adopted these international standards. In the light of this, Mangualde state that [38], over the last 30 years, the public sector has passed through a wave of reforms worldwide, usually towards the adoption of business-like practices as a way to better manage the public resources. With respect to financial reporting, these reforms have as cornerstones the adoption of accrual-accounting (AA) in place of the traditional cash-basis accounting and the discussions towards the use of a set of international accounting standards (IAS) such as the International Public Sector Accounting Standards (IPSAS) or the International Financial Reporting Standards (IFRS).

For example, Ouda states that some developed countries such as New Zealand, UK, and Australia and a few countries in Asia such as Malaysia, Singapore, Thailand, and Philippines have made essential changes in the government sector [10]. This reform had positive impacts, which have increased productivity and efficiency in the public 
sector. Ouda gives an example of a situation in New Zealand. He argues that New Zealand was suffering from economic crises, when the government implemented a chain of economic reforms. One element of these reforms was the government sector reform aimed to overcome the economic and financial crises. The public sector schemes for reform were:

- Separating private sector operations from government operations.

- Strengthening the accountability and transparency in the government sector.

- Designing management performance system to appraise the public sector performance.

- Shifting from an input-based budget to line performance-based budgeting system.

- Shifting from cash based to accrual accounting.

- Strengthening both internal and external auditing systems.

Another example of the public sector reform in a Latin American country is of Brazil. Mangualde indicates that the main purpose of accounting reforms, in Brazil, was to obtain more accounting disclosure and transparency in the government sector [38]. The outcomes of accounting reform in Brazil were: provision of more reliable accounting information to stakeholders in the country, strengthened accountability and transparency in the corporate sector, encouraged management practices, and thus increased productivity and efficiency and better allocated resources in the general budget.

However, in many developing countries, accounting system is still traditional and unable to perform the role expected of it, as in developed countries. Therefore, it needs some essential changes.

\section{Accounting system in developing countries}

Briston indicates that in the past, accounting system in developing countries was essentially designed and imposed by the colonial countries in order to meet their needs, rather than being helping in meeting the requirements of the host country [39]. These systems are most unlikely to be completely suitable for the different economic situation. Currently, these systems are inappropriate even for the colonial countries themselves. Similarly, Piers et al. claim that in many developing countries accounting records are routinely designed and poorly managed. The citizens cannot access the general and financial information. The researchers point out some problems, for instance, delayed closing accounts, incomplete transactions, weak internal audit, poor management accounting, deficient and incorrect records, and non-auditable systems and non-computerised system.

Hopper et al. indicate that transparency and accountability are regarded as the essential requirements of good governance [40]. Transparency comes with accountability; this is necessary as citizens require access to general information in order to judge government performance [40]. However, Mimba et al. claim that in the developing countries, the public sector is usually characterised by low institutional ability, weak procedures and practices, lower levels of accountability, inadequate transparency, and limited access to information and high level of corruption [41]. Similarly, Svensson claims that most anticorruption strategies depend on the strengthening accountability and transparency in the public sector. The main assumption is that better government system, regulations, and rules will increase transparency and thus will deter corruption practices. However, in many developing countries, regulation, management system, and financial institutions are weak and are often corrupt themselves. Therefore, it can be concluded that conventional systems and regulations are ineffective. Keeping this in mind, the testing and adoption of new systems and tools to enhance and increase accountability in the public sector should be at the frontline of research on corruption.

Another accounting problem in relation to developing countries is accounting staff. Pratap and Quintin argue that accounting staff and human resources are insufficient in many developing countries [42]. In addition, their accounting qualifications are not adequately sophisticated to deal with different financial situations. Therefore, developing countries should modify their accounting systems to meet their needs and to be suitable for contemporary institutions. In addition, they should design training programs to produce wellqualified accountants in order to be able to run and manage a new accounting system.

In this regard, The World Bank provides advice and suggestions for developing poor countries, fighting corruption, and modifying financial and management systems. In 1994 in its annual reports provided some suggestions about fighting corruption. It suggests that any country that desires to establish anti-corruption strategies should enhance its accounting system in the following ways:

- Adopting strong financial and management accounting system.

- Creating and developing their original professional accounting and audit standards.

- Implementing and supporting modern accounting standards such international accounting standards.

Another international organisation also plays a role in this regard, which is the United Nations Development Program (UNDP). In 2011, (UNDP) has proposed the development of countries through some reforms which are: management and accounting reforms that increase the independence of internal and external auditors and design computerised systems.

\section{Chapter conclusion}

To sum up, the literature review has illustrated three points: firstly, the corruption phenomenon in developing countries is regarded a serious problem which impedes their economic development Secondly, a financial system has weaknesses especially in relation to accounting and auditing system, where there is no accountability and transparency in the public sector. Thirdly, there is the need for comprehensive change in the accounting and auditing system.

In light of this result, one can formulate the research question which is, "What is the role of accounting reform in deterring corruption practices in government sector in Kurdistan region?"

\section{Methodology}

\section{Introduction}

The methodology opted for this research is the qualitative interpretive approach. The philosophical aspects of qualitative research depend on the interpretive approach to the social world and on the description of the human beings experiences [43]. Qualitative approach is a method for investigating and understanding a social phenomenon. As it is defined by [44], it is a form of social inquiry that focuses on the way people interpret and make sense of their experiences and the world in which they live. Further, researchers use qualitative 
approaches to explore the behaviours, perspectives, feelings, and experiences of people and what lies at the core of their lives [44]. The steps of qualitative research include determining the research question, collecting and analysing data, structuring general themes, interpreting the data and writing the results [45]

The scientific research process depends upon the philosophical lenses through which a researcher sees the world. These lenses make sense of the world, and about what is going on. Philosophical lenses help a researcher to work out the research questions he/she needs to ask, and what he/she might need to do to be able to get the answers to the research questions [46].

\section{Social research and philosophical viewpoints}

Social research is a process of seeking the truth. It includes gathering, analysing, interpreting, and reporting information. Therefore, the research process aims to predict and describe a phenomenon that has taken place in the surrounding environment of an organisation. Eventually, it is a methodical inquiry that provides information and knowledge to guide decision-makers [47].

Therefore, a researcher looking for truth must follow a particular philosophical approach which contains significant and meaningful assumptions about epistemology (theory of knowledge) and ontology (theory or the nature of being) [48]. These epistemological and ontological assumptions will clearly underpin the procedures and strategies of the research process. Before discussing the philosophical issues, it is useful to understand epistemology and ontology. Epistemology relates to the question of what is or should be considered knowledge. The essential point here is that social sciences can be investigated using the same method of the natural sciences. Ontology relates to the nature of reality. Through these assumptions researchers view the world.

\section{Interpretive paradigm}

Ryan et al. claims that the essential difference point for interpretive research paradigm is the assumption that social phenomena, including management and accounting, is not natural phenomena, but is socially constructed. These kinds of research follow an interpretive epistemological assumption which is predicated upon the belief that there are differences between people and the things of the natural sciences and, therefore, require the social researcher to recognise the subjective and social meaning of social phenomena. The interpretive paradigm promoters claim that it is necessary to understand the differences between human thoughts in our world as social researchers [49]. The ontology of the positivism paradigm assumes that reality is objective and exterior of human beings. However, the ontology of interpretive paradigm assumes that reality is socially constructed and its meanings are given by people [50].

Collis et al. explains that the interpretive paradigm accentuates the subjective aspects of social motion by focusing on the meaning of social phenomena, rather than the measurement. The interpretive paradigm is unlike the positivist paradigm that does not focus on the generalisation of findings. But, the findings can be approachable and have a broad reflection, particularly in cases where there are enough similarities to the primary research. Likewise, the ontology of this research is subjectivism (interpretivism) which emphasises that social phenomena and their meanings are being investigated by social actors [51]. Bryman and Bell indicate that this means that social phenomena are not only constructed through social interplay, but that they are in a continual case of revision.
The epistemological position of this research is interpretive and the ontological position is subjective, because the researcher believes that the topic of the research cannot be investigated by positivism (objectivism) paradigm. The topic cannot be recognised just by senses and stay at a distance, but by it needs to interplay with people who live and work in the real context of the phenomenon. Furthermore, the interpretive paradigm seems more appropriate in that the research is more qualitative, rather than quantitative research that deals with statistical data to get the answers of the research questions.

However, the main drawback of interpretive research is that firstly, the findings cannot be generalised because it gives way to subjectivity during collecting, analysing and interpreting.

Secondly, the outcomes from interview process can be interpreted from different perspectives by another researcher. Thirdly, because the number of respondents is small, a general theory cannot be built for a particular case. Fourthly, the questions are designed by the researcher that may lead to bias because he/she has his/her own perceptions and views about the subject. Finally, the results rely on the extent to which the respondents are honest with their answers [52].

The reason for selecting qualitative approach for this research study is: this research focuses on one case study, which is about the Kurdistan region and involves an in-depth investigation about the relationship between corruption and the region's accounting system. Therefore, interpretive approach will aid in the research, where the aim is to understand the enablers of corruption within the public sector.

\section{Case study}

There are different methods for gathering data for a research, and this considerably relies on the subject of the research study [45]. A case study, in this context, has been selected as the method for collecting data. The case study research is an intensive study about a single organisation, group, society or a country. Case study research is a methodical way to investigate a particular event or a particular phenomenon in its real and social context [53]. As it is defined by Yin in 1994, an empirical inquiry that investigates a contemporary phenomenon within its reallife context, especially when the boundaries between phenomenon and context are not clearly evident [54].

Robson looks at the case study as a strategy for scientific research to collect empirical data regarding a particular phenomenon [55]. In this context, he defines case study as - a strategy for doing research which involves an empirical investigation of a particular contemporary phenomenon within its real life context using multiple source of evidence.

A case study is a good tool for a researcher who would like to obtain information about the context of the research and its procedures [56]. The reason for adopting a case study is the flexibility and exploratory of the case study [55]. Yin claims that to answer questions such as how, why, and what of the result, a case study is a relevant tool to get these answers [54]. In addition, Easterby-Smith et al., have a similar argument they argue that the case study method is more interested in providing a clear picture of a particular phenomenon and behaviour [50].

\section{Strengths and weaknesses of case studies}

The key features of performing a case study are flexibility in design, holistic in view (it allows one to gather different perspectives about the same phenomenon or case at the same period of time), dynamic process, and more reflexivity of the researcher regarding the impact of the research process [56]. Furthermore, an individual case study in 
qualitative research provides the researcher an opportunity to examine, investigate, and deeply analyse a phenomenon under study when there is a lack of proper literature review [49].

However, case studies pose some of the following disadvantages:

1- The difficulty for the researcher to decide the scope of the case study.

2- The difficulty for the researcher to consider him/herself to be a neutral observer and the difficulty of reliability and validity of evidence.

3- The difficult for the researchers in accessing information that may be confidential to the organisations, which are under study [57].

Of the above, the last point is the most common disadvantage, especially in the developing countries because, where the majority of organisations either public or private, neither desire to share information nor let employees reveal information. The researcher of this study has experienced this difficulty during the semi-structured interview process.

\section{Steps in a case study}

Any researcher in order to conduct a case study research should follow the following steps [58].

Preparation: The researcher must survey the available theories which could be possibly applicable to the case study in question. This survey of previous theories will determine the path for the researcher to approach the case study.

Collecting evidence: The preliminary survey of theories will give indication of some sort of evidence which should be reviewed for the case study. Such evidence contains documentation, interviews, researcher observations and participant observations.

Assessing evidence: During the collection of evidence the researcher should confirm the reliability and validity of evidence. Reliability means the extent to which the evidence is independent. Validity means the extent to which the data is true.

Identifying and explaining themes: In a case study, different patterns and themes often appear. It is important for the researcher to link and connect the different themes and issues with the existing literature. In this regard, some themes and patterns will need further investigation, expansion of the model, collection of new evidence, and re-interpretation of the findings in order to harmonise the different themes. More importantly, in any single case study, the researcher should select the study's scope and limitations at the beginning of the research process.

Theory elaboration: If conflicts emerge among the themes and existing theories, it is important for the researcher to gather new evidence in order to solve these conflicts. In this regard, theories can be expanded to meet the requirements of the new situations.

The last step of a case study is writing a report about the main findings of the research study. This step will make the case study and its explanations clear and understandable to the readers. This not only includes writing down the findings of the research, but also the provision of sufficient evidence to persuade the readers that the researcher has a proper understanding about different aspects of the case study [59].

The researcher, adhering to the above steps, has gathered reliable and valid findings.

\section{Methods and types of a case study}

The researcher can use either the quantitative or qualitative methods or both in a single case study [46]. In addition, Scapens states that there are many types of case studies such as descriptive, illustrative, experimental, and exploratory. This research follows the explanatory qualitative case study. Explanatory case studies focus on particular cases in order to explain reasons for a particular practice in such cases [58].

This research is an explanatory case study of Kurdistan region and uses qualitative method to investigate the research question. Scapens argues that case study is very common in management, business, and accounting research since the focus is usually on an organisation or a sector [58].

There are many methods in a case study research to collect data such as textual analysis, observation, focus groups, semi-structured interviews and triangulation [59]. Since the research question focuses on the explanatory characteristic, how can reforms in the accounting system in Kurdistan region affect the corruption cases? the method of semi-structured interview was found to be a suitable tool to gather the required data.

The interview, in general, is regarded as one of the most effective methods for collecting qualitative data and has been broadly adopted in qualitative research. Usually, there are three different types of interview processes: structured, unstructured, and semi-structured. The last type is mostly preferred as it provides a free atmosphere for the interviewees.

The semi-structured interview has enabled the researcher to talk openly and freely with the respondents, unlike the structured interview, wherein the respondents cannot answer broadly in a structured interview. However, in the case of the respondents, semi-structured interviews may make them feel more convenient as they are given the opportunity to demonstrate and clarify their answers in long answers rather than in short answers [60].

The semi-structured interview is widely popular with researchers, because itis more flexible than other types of interview methods and in addition it gives scope for the respondents to reveal important facets of human behaviour. It is regarded as a powerful means of collecting data [61].

Furthermore, Schensul et al. indicate that the effectiveness of an interview could be maintained by considering the following points [62]:

(1) The story of the interviewee should be followed.

(2) The relationship should be maintained; and

(3) The interviewer's bias should be avoided.

\section{Background information about Kurdistan region}

Kurdistan region is a federal part of Iraq. It is located in the north of the country, borders Iran to the east, Syria to the west, and Turkey to the north. The area of this region is more than 80,000 square kilometres and its population is estimated to be more than 5.5 million. The Kurd people in Kurdistan region consist of about $95 \%$ and the remaining 5\% comprise the Turkmen, Assyrians, and Armenians. The formal language of the region is Kurdish (the formal webpage of Kurdistan Regional Government (www.krg.org).

The regional capital city of Kurdistan region is Erbil. The Kurdistan region geographically includes four main big cities, which are Erbil (the capital city), Sulaymaniyah, Duhok, and Kirkuk city (the richest 
oil city in the world). However, the last city (Kirkuk) is characterised by disputes between the central government of Iraq and the Kurdistan regional government; therefore, it is still politically governed by central government of Baghdad [63].

The Kurdish people have rebelled against the Saddam Hussein regime in 1991 after the first Gulf War. The first government, which is the Kurdistan Regional Government (KRG), was founded in July 1992 by the approval of Kurdistan Parliament after the first democratic election in May 1992 [64].

Kurdistan region has been constitutionally recognised by the Iraqi central government since 2003, after the Second Gulf War, when the Saddam Hussein regime was overthrown by the U.S army. Nowadays, the Kurdistan region has constitutional and official institutions, such as the presidency institution, parliament, government, judicial authority, and the private military forces that are known as Peshmerga [65]. More importantly, Kurdistan region is trying to become an independent state.

Currently, the Kurdistan Region has made significant improvement towards achieving a political and economic stability by practicing principles of democracy and hard work. Thus, it has become a prosperous and peaceful place among the other violent and unstable parts of Iraq [66]. However, Kurdistan region like many other parts of Iraq and other developing countries suffer from rampant corruption.

Despite the Kurdistan region having made significant progress with regard to the political and economic aspects (www.krg.org), there are many other areas that are still following traditional and out of date methods such as its financial and accounting system, banking and insurance system, and information technology. These areas suffer from real weaknesses that need reforms or essential changes in order to be able to deal with the current situations of their society.

\section{Interview process}

Initially, a preliminary field conversation was conducted through the formal interview. This early conversation was considered very useful to facilitate answers to the research question. The process of research includes elaborating the research question, collecting data, analysing the data, building general themes and making interpretations.

\section{Selecting respondents}

This research focuses on aspects of reform in government accounting and general budget, and their anticipated impacts on corruption practices. Therefore, it needs a detailed analysis and examination of the themes by the respondents who have a better understanding of the research topic.

The respondents were recruited from the Kurdistan government to allow the generation of valid and reliable data. The respondents have been recruited and interviewed from different government entities and organisations; these respondents include auditors, accountants, lectures from universities and other education institutions.

The researcher has contacted the interviewees through emails and social media platforms such Facebook. During this, many managers, accountants, auditors, academics, employees and other specialists have been contacted. A total of 10 semi-structured interviews through Skype were performed.

\section{Interview guide}

As a foundation for conducting these interviews, a short background about the research topic was given to respondents by emails. These explanations served as a guide to the interviews. The interview guide involved background of the research topic and questions related to the topic.

For coherence, the set of respondents in different institutions were asked identical questions. This helped the researcher to reduce the bias that may occur, especially if the researcher had interviewed only one category of respondents. In addition, this helped the researcher to collect information that could not have been acquired from only one category of respondents.

The amount of time spent for each interview was about 60 minutes. The semi-structured interviews were recorded and transcribed. All interview conversations have been performed in the Kurdish language. The researcher has tried to guide the interviewees towards the related subjects and to probe new issues emerging during the discussion. A short summary after each interview was written and reviewed. The issues of the subject which required additional investigation and discussion were prepared and added to the next interview guide.

Before the interview process began, respondents were asked to sign a consent form, but the researcher realised that this was very difficult for them. At the beginning of the interview process, the researcher introduced himself and explained a short background of the research topic and its main aim. The respondents were asked to acknowledge their approval orally.

Finally, the interview process was performed in the Kurdish language and translated to the English language. After transcribing interviews, to get general idea, a broad reading was done. New and important issues that required further explanation were highlighted.

The data were coded and revised systematically. Finally, the data were analysed and assessed manually.

\section{Interview questions}

The type of questions used in the interview was open-ended. The semi-structured interview was adopted for two reasons: firstly, there was a set of themes about accounting and corruption that required intensive investigation. Secondly, the questions linked to these themes could not be answered in closed-end questions or yes' and no' questions. The open-ended questions allow the interviewees to reveal their opinions smoothly and freely.

The interview consisted of three main open-ended questions, in addition to some other probing questions to support and promote the main questions.

Question 1: What are the common forms of corruption practices in the public sector in the Kurdistan region? Or in other words the opportunities for practicing corruption in the public sector.

Question 2: What are the main gaps and problems in the government accounting system in the Kurdistan region?

Question 3: In your opinion, what are the main aspects of accounting system that need essential changes in order to become more transparent and accountable and thus can be used as an anticorruption strategy?

\section{Chapter conclusion}

In this chapter, the methodology of the research was discussed in general. Also, different methodology aspects were included such as the definitions of qualitative method, philosophical approaches in 
social research, information about the case study, and a background about Kurdistan region; in addition, semi-structured interviews and some other information about the interview process and the interview questions have been highlighted in this section.

\section{Findings and Discussion}

\section{Introduction}

Saunders et al. argue that in qualitative research, there is a difficulty in finding a logical path to approach the collected data and analysis as it provides broad guidelines [49]. In order to overcome this difficulty, Saunders et al. suggest summarising, classifying, and structuring are the main steps of analysing data of the qualitative research. For this reason, the data have been summarised by reducing long statements into short statements. The results of the interviews have been categorised and themes have been developed. These themes have been examined keeping in mind the literature review and filling the gaps between the existing literature and the present study.

\section{First theme: Forms of corruption in the Kurdistan region}

In Kurdistan region, according to the answers of all interviewees, corruption is quite common and obvious. It is a widespread phenomenon in the entire government structure. The interviewees stated that bribery, fraud, abuse of public position and accounts manipulation, tax and customs evasion are the common forms of corruption in this region.

There are some areas in the public sector which are considered to be the most corrupt.

\section{Below is the brief discussion of each of them:}

1. Procurement, contracts, and government tenders: Essentially, these three areas have a strong relationship with money and thus are subject to corruption. Government employees and concerned parties exploit the weak systems and legal gaps and the lack of appropriate procedures and legal controls [67]. In this case, corrupt practitioners, in some procurement commissions, usually find suitable opportunities to gain private advantages by the conclusion of fictitious government contracts and tenders. In Kurdistan region, there is no appropriate system, especially an accounting system to deal with the prevention of each and every one of these important cases. The interviewees have illustrated that in the majority of corruption cases accountants and other employees function as intermediaries and brokers of corruption. The most common type of corruption in Kurdistan region is the procurement process. The employee who is responsible to purchase goods receives a bribe. The interviewee (R3) stated that: "This form of corruption is a frequent case in the general sector. For instance, the purchase commissions manipulate items in terms of quality, quantity, and price. According to my practical knowledge, most cases which I have reviewed have no adequate control in public organisations to review the purchase process. Further, import of construction materials is one of the situations where corruption cases occur frequently, since the price of construction items is difficult to investigate."

2. General resources collection: Resources, here, refer to different government taxes, customs, and other government resources. In these cases, money is also involved. Through the exploitation of these positions, the discounts and benefits are granted illegally in exchange for bribes and special favours. These areas have significantly reduced the national resources. For instance, in Kurdistan region, there are more than 10 international border crossing customs [68]; for e.g., the annual revenue of International Ibrahim Khalil crossing which is located between Kurdistan region and Turkey is about 350 million US dollars. However, only little amount returns to the general government treasury.

3. Granting of approvals, licenses and permits: This is another area that attracts corruption in the public sector. In Kurdistan, regional private companies, investors, and business owners usually pay bribes for approvals for starting a business. Government officials do grant approvals only after receiving the kickbacks of the applicant.

4. Bureaucratic corruption is widespread in Kurdistan region. There is a survey that shows $3.7 \%$ of citizens have reported paying bribes in Kurdistan [69].

5. Misuse of government resources: This includes the use of resources and government positions for fulfilling private gains. In these cases, an employee tries to obtain financial benefits from the use of government cars for private purposes of the employee or relatives such as brother, cousin, and family. Usage of mechanisms, equipment, buildings, and public facilities by employees for purposes different than those are allowed is also a form of corruption.

6 Exploitation of public office: People who are in a high position in Kurdistan government exploit their positions for financial gains. They spend most of their time searching for ways and means to enable them to increase the size of their wealth at the expense of the general interest. They also try to legitimise their illegal behaviours by exploiting the weakness of general system. For instance, the interviewee (R2) stated that: "While setting a proposal for a certain project, they exaggerate the cost of the project, for e.g. if the real cost of the project (A) 1 million US dollars, they inform government that the project needs 1.5 million dollars. On the other hand, while implementing the project they try to purchase materials of low quality with low price."

7. Smuggling funds: Some government officials in the Kurdistan region smuggle money which are obtained illegally. They deposit this in banks and capital markets in foreign countries. Others participating in money laundering buy properties outside of Kurdistan region. An interviewee (R9) stated that: "Many managers and employees who have high positions such as those working in tax authorities and customs own houses in Turkey and Dubai."

8. Tax and customs evasion: Many firms, businessmen, and investors from the private sector pay bribes to government officials in order to avail tax reductions or exemptions for a long time, or ease customs duties or be exempted or excluded by manipulating laws and procedures. Further, some traders pay bribes in order to import goods of low quality and thus, ease customs duties.

Determining the various forms of corruption is a difficult task. The points mentioned above do not necessarily limit the manifestations of corruption. The forms of corruption in Kurdistan region are manifold making it difficult for the researcher to discuss out all of them.

\section{Second theme: Current accounting system in the Kurdistan region}

The second theme is about the current government accounting system in Kurdistan region, which is based on the cash-basis system, where the majority of accounting procedures are processed manually.

Cash-basis system: The cash-basis system is the foundation for Kurdistan region's accounting. According to the cash-basis principles, transactions are recognised and recorded only when cash is paid or received. This means the revenues, expenditures, assets, and liabilities 
are only recognised when cash is received or paid [70]. As a result, the books of accounts are unable to show the real financial situation. The following are some shortages of the cash-basis system.

Firstly, the cash-basis system is unable to show real assets and liabilities accounts. It is unable to provide the government with adequate information about the total assets and liabilities in a given year, due to which some money is not paid or received on time (IFAC 97). Under cash-basis, a liability or asset is recorded only when a monetary transaction related to these occurs. As a result, a large amount of assets and liabilities are not revealed in the financial statements when appraising government's financial position and performance [71]. Furthermore, the accrued expenditures are also not recognised at the end of the year. Therefore, it can be seen how the cash-basis system misleads the financial situation of the government [72].

Secondly, earned revenues are not revealed under the cash-basis system. According to this system, the revenue is recognised in the financial reports when cash is received. In addition, the cash basis does not differentiate between current receipts and capital receipts [10].

Thirdly, under cash-basis accounting, information about total costs of goods and services is not reported until the cash is paid during the financial year. This indicates that the cash payments do not indicate general costs of the organisation during the period [10].

Lastly, the general value of inventory consumed during the period is not disclosed by the cash-basis system. As a result, the cash system is unable to adjust and measure real inventory accurately [70]. As the interviewee (R4) said: "From my point of view, cash-basis opens the doors for corruptors to achieve their private gains. So, as a consequence of applying the cash system, a large amount of the state's liabilities, revenues, costs, and expenses are not recorded in financial reports and are not paid attention to, during the appraisal of the government's financial situation and outcomes, or selecting expected revenue demands. In addition, the accrued expenditures of the government are similarly not recognised at the end of the fiscal year."

To sum up, cash-basis is ineffective in showing the real fiscal and economic position of governmental organisations. As a result, the government is unable to show appropriate transparency and accountability about its operations and activities. As discussed above, some of the shortages of the government accounting system are likely to be related to this very ineffective system. However, there are some other problems that have connection with accounting structure in general. The interviewee (R2) said that: "There is a chaos in the accounting aspects in Kurdistan region, where there is no uniform national accounting to be followed by all entities whether in public or in private sector."

The interviewees stated that different government institutions have different accounting systems. The harmonisation and coordination do not exist. This definitely leads to a case of uncertainty and discrepancy as far as the procedures and practice of accounting system are concerned. Some of the discrepancies arise due to the following factors:

- Government accounting is applied by the government sector.

- The Uniform Accounting System is applied by industrial and commercial sectors.

- Accounting system for investment activity is according to the investment plans of the Ministry of Plan.

- Accounting systems applied in banks and insurance companies.

\section{- Different accounting systems in the private sector.}

Also, in the Kurdistan region, there is a lack of accounting legislation. The accounting legislation is an important element to organise the accounting aspects. The interviewee (R7) said: "In the Kurdistan region thousands of national and foreign companies are working in different sectors and industries. Each company follows a particular accounting system and procedures, especially the foreign companies. These companies have contact with the government of Kurdistan in relation to taxes, exemptions, and fines. In this case, there is an opportunity for government officials to manipulate financial statements for those companies in regard to paying taxes, fines or granting licenses. Because there is no uniform accounting legislation about those aspects."

It is natural that these systems differ in terms of registering, recording, bookkeeping, accounting principles and rules, preparing financial statements and financial disclosure which will overall lead to different results. To sum up, in Kurdistan region, the government accounting system is based on the cash system. In addition, the government accounting system does not provide the necessary information about government activities and performance. There is no adequate transparency and accountability; citizens do not have opportunity to get information about government's activities. As a result, it can be concluded that the present accounting system in Kurdistan region suffers from the following flaws:

- It is unable to provide comprehensive financial statements and reports in a relevant time.

- It does not adhere to the international accounting principles.

- It is unable to provide appropriate information for general budget purposes.

- It is unable to provide information for financial analysis purposes.

Finally, in the Kurdistan region, some accounting problems are related to accounting staffs.

The next theme will illustrate this problem.

\section{Third theme: Staff qualifications and accounting education}

An accounting system has six main components: principles and procedures, data, software, information technology, internal control, and human resource. The human resource part (accountants and who runs the system) is the main input for an accounting system [73].

In regard to the situation of Kurdistan region, the government accounting is managed by less capable and ineligible accountants and auditors. Referring to the Kurdistan situation, it was observed that the majority of government accountants and auditors do not have competent accounting knowledge and information. In this context the interviewee (R3) stated: "In Kurdistan region managers generally are less trained. Thus, they choose low accounting systems because they do not have proper knowledge about new accounting tools and procedures. For instance, in the public manufacturing sector, traditional cost system (job system) is still in use. Overhead costs are usually allocated according to job system. This opens the door for employees to manipulate the transaction because it is not accurate system."

Further, some accountants and auditors in the public sector basically do not have accounting certificates. As is stated by the 
interviewee (R10): "If you look to some government organisations in different ministries, you can see many employees in the accounting departments do not have accounting certification. For example, the general manager of the Regional Central Bank does not have accounting certification."

This lack of qualified staff is regarding the critical problem in the public sector in Kurdistan region. This includes the lack of qualified clerks, accountants, and auditors. This shortage may relate to the fact that there is no proper accounting education in universities and institutions. In the universities, old accounting curriculum is still in use and not updated. About this problem the interviewee (R5) said: "In 2007, in my final year of bachelor's degree, I had one module, which was Auditing, the book for this module was published in 1970."

In addition, in this region, many lecturers and faculty staffs are also not knowledgeable about contemporary accounting issues. Finally, the universities and higher education institutions in the Kurdistan region are not in a position to offer proper accounting education that meets the requirements of the new contemporary and market economy. Teachers and faculty staff who are teaching accounting do not have the ability to teach new accounting methods and standards. The interview (R7) stated: "From my practical experience, in Kurdistan region new graduation of accountants, they do not have sufficient knowledge about accounting issues. This tells us that universities and other educational institutions in our region do not provide suitable accounting education that meets the requirements of contemporary challenges."

\section{Fourth theme: The role of auditors}

Accountants should participate in efforts to reduce corruption as they hold sensitive positions in the management structure [74]. Besides accountants, auditors are also essential in deterring fraud and corruption practices. Internal auditors, in particular, have a wide attention and understanding of events which are happening during the financial year [75]. Auditors are regarded as the eyes and ears of management and they can deliver a vital role in the anticorruption strategies. Correspondingly, external auditors encourage managers, employees, and accountants to stay away from manipulative transactions and falsifying financial statements. Both internal and external auditors can contribute to improving regulations of an organisation. As is stated by Virginia et al. [76], Traditionally, the role of external auditors has been perceived as the most important factor in detecting and preventing financial statement fraud. In recent years, however, the entire corporate governance system (board of directors, audit committee, top management team, internal auditors, external auditors, and governing bodies) is responsible for ensuring the integrity, transparency, and quality of financial statements.

However, the situation in Kurdistan region is different. Many accountants and auditors are involved in corruption cases instead to preventing it. On the one hand, as stated in the previous theme, accountants and auditors are generally not qualified to practice accountancy. On the other hand, in any profession there are some ethical standards and considerations that should be taken into account by the practitioners of these professions. However, as stated by the interviewee (R4): "Through reviewing many big corruption cases, it is clear that there is an agreement between who work in accounting departments particularly auditors and private sector to legitimise the illegal acts e.g. paying bribe to an external auditor to hide real profit to be used to tax evasion."

\section{Fifth theme: General budget system}

The general budget is the process to determine general resources and expenditures for the subsequent period normally for a year, based on previous data and facts according to scientific principles. Initially a budget process is included four stages; formulation, setting, implementation and control [77].

In the Kurdistan region, the general budget process is regarded a suitable sphere for practicing corruption. All respondents have agreed that setting and implementing of budget process have essential gaps. For instance, setting the budget is not based upon any scientific strategies, as for the majority of government projects, the essential costs are randomly determined and exaggerated. For instance, the interviewee (3) stated that: "There was a project, which was (the establishment of a big general hospital), in Sulaymaniyah city, its cost was 100 million dollars. Through the audit process we realised that the money has allocated for this project more than five times."

Further, people do not have enough information about the sources of government income. There is no transparency about the allocation of general resources in the budget and the government expenditures. The process of implementing the budget also does not follow the instructions. There is no adequate control to observe the stages. Moreover, the general budget system does not adapt to the international standards. There are some serious delays in setting and executing the budget. The budget delay became a normal matter in this region. For example the interviewee (R8) said: Maybe every year the process of preparing and approving the general budget has been postponed, e.g. the general budget for 2013 was approved in the middle of July 2014. This, in my opinion, opens a door for practicing corruption because spending general expenditures is not based on new budget instructions as well as collecting government resources such as taxes and customs."

\section{Sixth theme: Forms of accounting reform in Kurdistan region}

The last question of the interview process was in your opinion what are the essential forms of accounting reform process in Kurdistan region? The interviewees were referred to various forms of reform. The main forms were summarised as follows.

Shifting from cash-basis to accrual-basis: There is another kind of accounting, which is the accrual-basis. Producing financial statements under accrual-basis is more transparent and includes all the financial events which have happened during a specific period [78]. Further, Hepworth indicates that the accrual-basis system provides more transparent information and is more reliable than cash-basis. Accrualbasis also recognises revenues and expenses, apart from the cash receipts and payments [79].

In this regard, Torres states that accrual-basis accounting is a powerful weapon to combat fraud and corruption in government sector [80]. Further, Torres adds: accrual-based fiscal indicators provide better information about the sustainability of fiscal policies, provide a stronger basis for government accountability and a better measure of the effects of government policies [they also] provide better measures of organizational efficiency and effectiveness, and reduce opportunities for fraud and corruption [80].

Therefore, in fighting corruption, accrual-basis is more relevant than the cash-basis method. This is so because financial statements and reports based on accrual-basis provide accurate information about:

- How a government funds its activities and to what extent meets its cash requirements.

- How it allows users to evaluate a government performance and its abilities to meet its commitments and liabilities. 
- Government financial situation and its commitments and liabilities.

- Government revenues and their sources and how these resources are allocated in general budget.

- The financial position of the government and the changes in it during a given year.

- Information for national economic planning and GDP [81].

Thus, according to the answers of the interviewees, switching to the accrual-basis accounting systems is necessary as the traditional cashbasis is now regarded to be outdated and no longer adequate, especially because it is unable to show the correct financial position, planning, and control in public sector organisations. Therefore, the first priority of the government of Kurdistan region is shifting from cash-basis to accrual-basis in order to be able to fight against corruption.

Adopting the International Accounting Standards (IAS): The IASs are a set of international standards that were invented by international organisations and federations of accounting. The main aim of IASs is providing international harmonisation and coordination in relation to accounting issues. Further, financial statements under IAS have comparability, accuracy, reliability, and validity [82].

Adopting IASs has possibly many benefits; for example, it leads to the national and international coordination of a country. It encourages values such as accountability, responsibility, transparency, and fairness [37]. These values are essential for the enhancement of the operations within the public sector. In regard to corruption issues, it will enable a country to fight corruption better due to these accounting international efforts [83]. Therefore, the interviewees suggested, the Kurdistan government create national accounting standards, while taking into account the cultural and social considerations, all the while keeping in line with IASs.

Budget reform: An accounting system has a direct relationship with the general budget of a country [84]. Therefore, another aspect of reform is the general budget reform. Audio (2013) argues that the lack of a proper accounting system could possibly undermine the role of the budget. The budget system is linked to the accounting system. Therefore, the budget should depend on the basis of accounting used; thus, budget reform makes accounting reform unavoidable. In this regard, Kudo in 2010 states that [85], public reform policies that include restructuring of government institutions and public organizations, modernization of budgeting processes, rationalization of financial policy and its implementation, change of human resource management, renewal of public management and public service delivery, review of public/private partnership, and use of Information and Communication Technology (ICT') to improve the managerial process as well as to communicate better with the citizens.

The government of Kurdistan can overcome the shortcomings of the traditional budget, which is the line-item budget, by shifting to the program-performance budget. This new budget can improve the allocation process and provide a basis for choosing between the attainable alternatives. The program-performance budget, organises the link between the inputs and the outputs and it tries to use the resources efficiently and effectively in order to achieve the target objectives. In short, it focuses on government expenditures and their outcomes and provides information that can be used to appraise general budget outcomes. Similarly, Ouda argues that applying the program-performance budget can [10]:
- Limit the general expenditures to the items allocated in the general budget.

- Make the implementation of budget easier and more transparent, accountable, and manageable; and

- Make general budget flexible and adaptable to all-economic situations and conditions.

Accounting education: The outcomes of this situation are the shortage of professional accountants in the government sector. There is the need to add contemporary accounting curriculum to universities and institutions in order to provide student competencies and skills that will help them to deal with illegal behaviours and corruption cases. The main challenge is the lack of qualified accounting staffs who are able to understand these new requirements and thus be able to run the new accounting system. For example, one part of accounting reform will include adopting the international accounting standards. It is difficult for accountants and auditors to follow these standards without previous information and understanding.

Therefore, this situation calls for a proper accounting education in the Kurdistan region. Thus, in order to overcome this problem, Kurdistan government is required to renew and develop the accounting curriculum in universities and introduce contemporary and necessary subjects related to accounting issues.

Strengthening the auditing system through the Supreme Audit Board (SAB): SAB has the authority to audit and control all organisations, whether public or private. It is regarded as safety valve, which makes sure that organisations follow the necessary legislations and rules in their accounting and auditing processes. In many countries, $\mathrm{SAB}$ has the absolute authority [86]. However, in Kurdistan region $\mathrm{SAB}$ fails to perform its real role and is not independent. Therefore, $\mathrm{SAB}$ is required to be powerful and authorised entirely. SAB can also take action to prevent and minimise corruption. As the interview (R2) stated that: "The Kurdistan government should reinforce laws that should guarantee SAB's independence by reinforcing laws, allow publishing a wide range of its reports, give them authority entirely to check the different level of public sector organisations at any time, and implement its recommendations. Further, SAB should be responsible for the recruit, hire, firing its staff."

The government of Kurdistan should grant $\mathrm{SAB}$ an adequate power to access the records of all public organisations in a timely manner, have authority to question and interview managers and their employees at any time, and they show complete cooperation with the SAB staff. In addition, the new regulations should provide punishments for those who do not comply with the requirements and regulations or do not provide necessary information for the SAB staffs.

Information technology: The information technology has an impact in many fields, accounting system being one of the fields which was significantly affected by the information technology [87]. In addition, currently, accounting processes mainly depend on computer programmes particularly in the developed countries.

As stated in the second theme, the traditional accounting system is based on manual work, therefore, the Kurdistan government should consider using the design information technology in the public sector. The interviewee (R5) stated: "From my practical experience, I realised that the information system in Kurdistan region is inefficient and has some limitations, for example, it's unable to provide reliable, accurate, and up-to-date information in a cost-effective way. Thus, designing a 
network to connect all government organisations with each other is regarded a good step forward towards fighting corruption."

To sum up, the interviews made clear that the corruption phenomenon is disseminated from the high level government officials to the low level. According to the findings of the study, many cases of corruption are found to be the result of the ineffective accounting and budget system of the Kurdistan region. Some aspects of reform, as suggested by the respondents, may help the government to address the weaknesses of its accounting and budget system and thus fight corruption easily. However, on the one hand, besides the aim of fighting corruption there are also some challenges that make the reform process necessary.

\section{Seventh theme: Challenges towards accounting reform}

Globalisation: Globalisation is imposing significant pressure on countries across the world to make radical changes to the systems, accelerate responsiveness, and open the doors for increasing local and foreign competition. Globalisation demands governments and organisations to harmonise their goals with each other. The harmonisation process may increase economic development and decrease discrepancies in goals between the private and public sector on the one hand and between the national and international goals on the other hand. Therefore, there is a need for proper government system in order to be able to deal with globalisation and its requirements [88].

International pressure: Some concerned international organisations such as The World Bank (WB), International Transparency Organisation (IT), and International Monetary Fund (IMF) are pressurising countries, particularly the developing and transitional economy countries, to make changes in their political, economic, and financial fields. These organisations require countries to be transparent and accountable. In addition, they encourage countries to reform their accounting systems by granting international loans and aids [89].

National coordination and integration: Another reason to make changes in one's accounting budget system is to achieve coordination and integration among different public organisations. Ouda argues that in many Arab countries [10], the national financial strategic planning has tended to be scrappy and there is no synergy and coordination at the national level. There is no relation between budget objectives and the macroeconomic objectives; there is a cause of financial chaos. As a result, many government projects are prone to implementation failure or long delays. A way for governments to overcome this problem is by reforming their accounting and budget system. Such a reform will force all government organisations to adopt the same system and procedures and thus, will unite the efforts towards achieving national objectives.

\section{Conclusion, Limitations, Ethical Considerations}

\section{Conclusion}

The findings of this research explain that Kurdistan region is suffering from various forms of corruption in its public sector. Corruptors often use accounting and budget procedures to legitimise their corrupt practices for deriving private gains on account of public resources. With regard to the accounting and budget system, there are some serious shortages and gaps in the operations and procedures of the government sector. These gaps have seeped into the heart of many accounting and budget procedures.

According to the statements of all respondents of the study, the government accounting system follows the cash-basis approach and is thus, outmoded and cumbersome. The system does not record assets, liabilities, revenues, and expenditures unless they result in cash transactions of a particular financial year; thus, making many of them invisible.

The budget system is based on the line-item system. This system does not accurately show the amount of general resources and expenditures. Thus it does not afford an appropriate accountability and transparency, in the process preventing people from accessing government information. In addition, the allocation process is not based on any scientific method, and for a majority of government projects the costs are allocated randomly.

In Kurdistan region, internal and external audits are weak. The Supreme Audit Board (SAB) does not play its role effectively, as it is still not independent. For many government projects, SAB cannot investigate their costs and only observes their execution stages. Also, with respect to the accounting staff, in Kurdistan region, many accountants and auditors are not qualified. Therefore, these shortages and gaps within the public sector have led to an increase in the corruption practices.

The following essential reform steps have been suggested by respondents: shifting from cash-basis to accrual-basis and line-item budget to performance programme budget, strengthening the role of audit and $\mathrm{SAB}$, changing the accounting curriculum, training accountants and auditors and designing information technology. It is believed that these steps may aid to some extent in deterring the corruption practices.

However, this research does not assert that an effective accounting system is the only solution to deter the corruption practices in the public sector of Kurdistan region. There may be other variables such as the political, social, cultural, and legal systems that also affect the corruption phenomenon in a country, and these should not be ignored. This is considered to be a limitation and to address this, future research can be conducted to investigate corruption practices in depth by taking into account these variables.

\section{Limitations}

Despite the sensible power of qualitative research, some limitations have been noted during the study. The limitations are with respect to the chosen approach, methodology, and methods followed. Johnson has identified three main disadvantages to qualitative research: firstly, its failure to manage independent variables, secondly, it may lead to incorrect interpretation, and thirdly, it presents a weakness of power to randomise. These problems cannot be overcome entirely; they are also relative from a case study to another [14].

Taking this into consideration, it can be said that this research was conducted amidst these limitations. The researcher has encountered some constraints. The process of recruiting respondents was considered the most difficult task and was time consuming, because the distance between the researcher, the environment of the case study (with refer to Kurdistan region), and the topic was very sensitive, and the respondents paid attention to some considerations such as political, social, and cultural.

The second was the limitation of generalizability as the number of respondents was small, which makes it difficult to generalise the findings. The researcher tried to involve a large number of respondents; however, due to the scope and limitations of time, the number of interviewees was limited to only 10 . In regard to subjectivity, the 
researcher tried to mitigate its impacts as much as possible in order to increase the reliability and validity of data.

The third limitation is with respect to the semi-structured interview, which is characterised by linguistic variability, wherein the phrases and words used may have different meanings. It is difficult for a researcher to interpret them and put them in correct places [90]. Since the interviews were conducted in Kurdish, in this case, the answers were more likely to lose some essential meanings when translated to English language.

In the final face-to-face interview, wherein the topic of discussion was the corruption and accounting in Kurdistan region, the researcher did not have the opportunity to travel to the area of the study in order to collect primary data. The information was collected via an online Skype session. Thus, the information gathered through this kind of interview is considered to be less reliable than a face-to-face interview.

\section{Ethical considerations}

The ethical considerations have been fulfilled by the researcher at the outset of the field work. The researcher has obtained the ethical approval form which was made mandatory by the university. As part of the ethical consideration, the respondents were required to review the consent form and sign it, before taking part in the interview. All interviewees have signed the consent form. The respondents were assured of anonymity and confidentiality their names would not be revealed. The questions were designed to collect confidential data from the respondents without revealing their names. Further, the results of the interviews were personally transcribed by the researcher to protect the respondent's anonymity.

\section{Acknowledgements}

- First of all, it would not have been possible without the help of ALLAH then the prayers of my parents

- I would like to express my deepest gratitude to my supervisor, Dr. Pinar Guven-Uslu, for her wonderful guidance, without her I would never have been able to finish my dissertation.

- Also, I would like to thank my wife (Nihaya) for her help and patience with me.

- Finally, I would also like to thank my brother Mr. Ameer who was always supported me and arranged for me the interview process with respondents in Kurdistan region.

- This dissertation would not have been possible without their help and support.

\section{References}

1. Mauro $P$ (1998) Corruption: causes, consequences, and agenda for further research. Finance and Development 35: 11-14.

2. Tanzi V, Davoodi H (1998) Corruption, public investment, and growth. Springer Japan pp. 41-60

3. Khan M (2006) Determinants of corruption in developing countries: the limits of conventional economic analysis. International Handbook on the Economics of Corruption pp. 216-244

4. World Bank Report (1997) Helping Developing Countries Combat Corruption.

5. Hwang J (2002) A note on the relationship between corruption and government revenue. Journal of Economic Development 27: 161-176.

6. Spector BI (2005) Fighting corruption in developing countries: strategies and analysis. Bloomfield, CT: Kumarian Press p. 312.

7. Sandholtz W, Koetzle W (2000) Accounting for corruption: Economic structure, democracy and trade. International studies quarterly 44: 31-50.

8. Bhargava VK, Bolongaita EP (2004) Challenging corruption in Asia: Case studies and a framework for action. World Bank Publications.
9. Malagueño R, Albrecht C, Ainge C, Stephens N (2010) Accounting and corruption: a cross country analysis. Journal of Money Laundering Control 13 372-393.

10. Ouda HA (2003) Public Sector Accounting and Budgeting Reform: The Main Issues Involved with Special focus on the Arab World. Economic and Social Commission for Western Asia (ESCWA), Beirut, Lebanon.

11. Haller D, Shore C (2005) Corruption: anthropological perspectives. Pluto Press

12. Génaux M (2004) Social sciences and the evolving concept of corruption Crime, law and social change 42: 13-24.

13. Campos NF, Dimova RD, Saleh A (2010) Whither corruption? A quantitative survey of the literature on corruption and growth.

14. Johnston M (2005) Keeping the answers, changing the questions: Corruption definitions revisited 35: 61-76.

15. Mo PH (2001) Corruption and economic growth. Journal of comparative economics 29: 66-79.

16. Lambsdorff JG (2006) Causes and consequences of corruption: what do we know from a cross section of countries. International handbook on the economics of corruption 1: 3-51.

17. Rabl T (2008) Private Corruption and Its Actors: Insights into the Subjective Decision Making Processes. Pabst Science Publishers.

18. Transparency International 2004 Annual Report (2004), University Press, USA

19. Kaufmann D (1997) Corruption: the facts. Foreign Policy 107: 114-131.

20. USAID (2005) USAID Anticorruption Strategy. Washington DC, USAID.

21. Deflem M (1995) Corruption, law, and justice: A conceptual clarification. Journal of Criminal Justice 23: 243-258.

22. Vargas-Hernández JG (2009) The multiple faces of corruption: typology, forms and levels. Forms and Levels pp. 1-19.

23. Amundsen I (2000) Corruption: definition and concepts. Bergen: Utstein AntiCorruption Resource Centre.

24. Singleton TW, Singleton AJ (2006) Fraud auditing and forensic accounting (4thedn) John Wiley and Sons.

25. Andvig JC, Fjeldstad OH, Amundsen I, Sissener T, Søreide T (2001) Corruption: A review of contemporary research. Chr. Michelsen Institute. Approaches, SAGE, London.

26. Okafor B (2004) Strategic approach to reduction of employee, theft fraud and embezzlement. Niger Account 37: 3-5.

27. MacDonald R, Majeed MT (2011) Causes of corruption in European Countries: History, law, and political Stability. University of Glasgow University of Glasgow.

28. Mungiu-Pippidi A (2013) Controlling corruption through collective action. Journal of Democracy 24: 101-115.

29. Shabbir G, Anwar M (2007) Determinants of Corruption in Developing Countries. The Pakistan Development Review 46: 761-764.

30. Chapman D (2002) Corruption and the education sector. Sectoral Perspectives on Corruption, prepared by MSI Sponsored by USAID, DCHA/DG.

31. Bardhan $P$ (1997) Corruption and development: A review of issues. Journal of economic literature 35: 1320-1346.

32. Rock MT, Bonnett H (2004) The comparative politics of corruption: Accounting for the East Asian paradox in empirical studies of corruption, growth and investment. World Development 32: 999-1017.

33. Leff NH (1964) Economic Development through Bureaucratic Corruption American Behavioural Scientist 8: 8-14.

34. Everett J, Neu D, Rahaman AS (2007) Accounting and the global fight against corruption. Accounting, Organizations and Society 32: 513-542.

35. Wu X (2005) Corporate governance and corruption: A cross-country analysis Governance: An International Journal of Policy, Administration and Institutions 18: $151-170$.

36. Kimbro MB (2002) A cross-country empirical investigation of corruption and its relationship to economic, cultural, and monitoring institutions: An examination of the role of accounting and financial statements quality. Journal of Accounting, Auditing and Finance 17: 325-350. 
Citation: Ghaffoori A (2016) The Role of Accounting Reform in Deterring Corruption Practices in the Public Sector: A Case Study in Kurdistan Region. J Bus Fin Aff 5: 229. doi: 10.4172/2167-0234.1000229

37. Barth ME, Landsman WR, Lang MH (2008) International accounting standards and accounting quality. Journal of accounting research 46: 467-498.

38. Mangualde BR (2013) Perceptions of benefits and challenges of public sector accounting reforms: a cross-sectional comparison between Brazilian and English local governments. University of Birmingham, England.

39. Briston RJ (1978) The evolution of accounting in developing countries International Journal of Accounting Education and Research 14: 105-120.

40. Hopper T, Tsamenyi M, Uddin S, Wickramasinghe D (2009) Management accounting in less developed countries: What is known and needs knowing. Accounting, Auditing and Accountability Journal 22: 469-514.

41. Mimba NPSH, Helden GJV, Tillema S (2007) Public sector performance measurement in developing countries: A literature review and research agenda. Journal of Accounting and Organizational Change 3: 192-208.

42. Pratap S, Quintin E (2006) The informal sector in developing countries: Output, assets and employment. Research Paper, UNU-WIDER, United Nations University (UNU), Japan

43. Patton MQ (2005) Qualitative research. John Wiley \& Sons, Ltd.

44. Holloway I, Wheeler S (2013) Qualitative research in nursing and healthcare John Wiley \& Sons.

45. Creswell JW (2013) Research design: Qualitative, quantitative, and mixed methods approaches. Sage publications.

46. Bryman A (2003) Quantity and quality in social research. Routledge.

47. Cooper DR, Schindler PS, Sun J (2006) Business research methods. McGrawhill, New York.

48. Guba EG, Lincoln YS (1994) Competing paradigms in qualitative research Handbook of qualitative research 2: 163-194

49. Saunders M, Lewis P, Thornhill A (2009) Research methods for business students. Financial Times/Prentice Hall, Harlow, England.

50. Easterby-Smith Mark, Thorpe R, Jackson PR (2008) Management Research Business and economics, SAGE pp. 1-351.

51. Zimmer L (2006) Qualitative meta-synthesis: a question of dialoguing with texts. Journal of advanced nursing 53: 311-318.

52. Ghauri PN, Grønhaug K (2005) Research methods in business studies: A practical guide. Pearson Education.

53. Gerring J (2006) Case study research: principles and practices. Cambridge University Press.

54. Yin RK (1994) Case Study Research: Design and Methods, SAGE, London p. 240.

55. Robson C (1993) Real world research: A resource for social scientists and practitioners- researchers. Massachusetts: Blackwell Pushers.

56. Eisenhardt KM (1989) Building theories from case study research. Academy of management review 14: 532-550.

57. Baxter P, Jack S (2008) Qualitative case study methodology: Study design and implementation for novice researchers. The qualitative report 13: 544-559.

58. Scapens RW (1990) Researching management accounting practice: the role of case study methods. The British Accounting Review 22: 259-281.

59. Strauss A, Corbin J (1994) Grounded theory methodology. Handbook of qualitative research pp. 273-285.

60. Bryman A, Bell E (2007) Business Research Methods. Oxford.

61. Louise Barriball K, While A (1994) Collecting Data using a semi-structured interview: A discussion paper. Journal of advanced nursing 19: 328-335.

62. Schensul SL, Schensul JJ, LeCompte MD (1999) Essential ethnographic methods: Observations, interviews, and questionnaires. Rowman Altamira p. 318.

63. O'Leary B, McGarry J, Salih K (2006) The future of Kurdistan in Iraq. University of Pennsylvania Press.

64. Karim KH, Koyi H, Baziany MM, Hessami K (2011) Significance of angular unconformities between Cretaceous and Tertiary strata in the north western segment of the Zagros fold-thrust belt. Geological Magazine 148: 925-939.

65. McGarry J, O'Leary B (2009) Must pluri-national federations fail? Ethnopolitics 8. 5 -25
66. Aslan S (2011) Everyday forms of state power and the Kurds in the early Turkish republic. International Journal of Middle East Studies 43: 75-93.

67. Basheka BC (2009) Procurement planning and local governance in Uganda: a factor analysis approach. International Journal of Procurement Management 2: 191-209.

68. Chorev M (2007) Iraqi Kurdistan: The internal dynamics and statecraft of a semistate. Al Nakhlah: The Fletcher School Online Journal for Issues Related to Southwest Asia and Islamic Civilization pp. 1-11.

69. Doski SA (2015) The necessity of issuing a corporate governance code for the Kurdistan Region. Journal of Finance and Accountancy 18: 1-19.

70. Jones R, Pendlebury M (2000) Public sector accounting. Business and Economics, Financial Times Princeton Hall p. 278.

71. Peter VM (2005) From cash to accrual budgeting and accounting in the public sector: The Dutch experience. Public Budgeting \& Finance 25: 32-44.

72. Frederick TC (1983) Cash or Accrual Basis Accounting-Which System is better for the Law Firm. Legal Econ 9: 51.

73. Romney M, Steinbart P, Mula J, McNamara R, Tonkin T (2012) Accounting Information Systems. Australasian Edition, Pearson Higher Education, AU.

74. Harding N, Ren M (2007) The importance in accounting of ambiguity tolerance at the national level: Evidence from Australia and China. Asian Review of Accounting 15: 6-24.

75. Balkaran L (2013) Auditing the Corporate Governance Effort in an Organization. EDPACS 48: 12-18.

76. Virginia A, Eleni K, Dimitrios P, Chrysoula X (2009) The role of financial accounting information in strengthening corporate control mechanisms to alleviate corporate corruption. University Macedonia.

77. Lienert MI (2005) Who controls the budget: the legislature or the executive? International Monetary Fund. London: SAGE Publications Inc., London: Thomson Learning. pp. 38-47.

78. Dechow PM (1994) Accounting earnings and cash flows as measures of firm performance: The role of accounting accruals. Journal of accounting and economics 18: 3-42.

79. Hepworth N (2003) Preconditions for successful implementation of accrual accounting in central government. Public Money \& Management 23: 37-44.

80. Torres L (2004) Accounting and accountability: recent developments in government financial information systems. Public Administration and Development 24: 447-456.

81. Vinnari EM, Näsi S (2008) Creative accrual accounting in the public sector milking 'water utilities to balance municipal budgets and accounts. Financial Accountability and Management 24: 97-116.

82. Wallace RO (1990) Survival strategies of a global organization: The case of the International Accounting Standards Committee. Accounting Horizons 4: 1.

83. Scofield B, Wilhelm $P$ (2004) International accounting standards and corruption Mimeo, University of Texas, Permian Basin

84. Ateetanan P (2001) Country Report Thailand. In 12th International Workshop for Information Policy and Management in the Public Sector, November, Tokyo, Japan.

85. Kudo H IIAS (2012) What Capacity-Building needed for the trustful CIO? : How to educate and train new generation of $\mathrm{ClOs}$ in Japan. International Congress Mérida, Yucatán, Mexico.

86. Dye KM, Stapenhurst R (1998) Pillars of integrity: the importance of supreme audit institutions in curbing corruption. Economic Development Institute of the World Bank.

87. Hollander A, Denna E, Cherrington JO (1999) Accounting, information technology, and business solutions. McGraw-Hill Higher Education.

88. Fulin C (2002) Overcoming institutional barriers and sociocultural conflicts in China. Newsletter.

89. Godfrey AD, Devlin PJ, Merrouche MC (2001) A diffusion-contingency mode for government accounting innovations. In International Comparative Issues in Government Accounting. Springer US pp. 279-296.

90. Willig C (2008) Introducing qualitative research in Psychology: Adventures in theory and method. (1stedn), Open University Press, UK. 